\title{
Local Governance Network in Sustainable Development of Featured Commodities in Central Mamuju Regency
}

\author{
Arsal Aras ${ }^{1}$, Muhammad Akmal Ibrahim², Badu Ahmad ${ }^{3}$, Didik Iskandar ${ }^{4}$ \\ Student of Doctoral Program Public Administration Hasanuddin University ${ }^{14}$, Department \\ Administration Science of Hasanuddin University ${ }^{23}$, South Sulawesi Province, Indonesia
}

\{arasarsal.aat24@gmail.com\}

\begin{abstract}
Governance network is a study that focuses on the interaction and coordination between actors in public governance. The development of sustainable regional featured commodities is an effort to improve the quality and quality of regional potential so that they can be widely utilized. The purpose of this research is to analyze and explain the application of local governance network dimensions in the development of regional featured commodities in central mamuju regency through components in the local governance network concept. The research method is descriptive qualitative with data collection techniques, location observations, interviews, and documentation. The research location is the office of the agriculture service of central mamuju regency. The results of the study found that efforts to develop regional featured commodities in a sustainable manner were carried out through regional action plans. The application of the governance network concept in the sustainable development of regional featured commodities still needs to optimize the role of actors through strengthening capital, bonding models, policy instruments, administrative strategies, accountability structures, and performance management systems.
\end{abstract}

Keywords: network governance; development; featured commodities; sustainable

\section{Introduction}

The rapid development of community needs in various sectors in the current era makes it important to improve the quality of government services to public needs. All government activities that are oriented towards meeting basic public needs are increasingly forcing the government to present good governance. Public administration is closely related to several main studies such as policy studies, governance studies, and public studies itself, agus dwiyanto, 2016 [1].

As one part of the scope of public administration studies, governance studies generally pay attention to at least an important issue, which distinguishes it from the conventional public administration tradition. There are three main dimensions that underlie the study of governance studies, namely, institutions or institutions, values and processes. The three main dimensions of governance are the scope of the discussion on governance. Governance studies care about blended institutions in managing public affairs and interests, by developing various concepts and theories that are able to explain various forms of cooperation between government institutions and government agencies. The form of cooperation between institutions within the 
scope of the governance study is categorized as a discussion on governance networks, osborne, $20102[2]$.

The discourse on the definition of governance is also mentioned by Merilee s. Grindle 1980 [3]. In a broader topic regarding the relationship between the concept of good governance and the growing promise of development and poverty reduction. In defining governance, grindle compares various definitions proposed by an official agency (World Bank, UNDP, IMF, DFID And Usaid) and scholars (Hyden, Kaufmann and Hewitt). Grindle argues that there are common components and differences between these definitions of governance. Grindle stated that the component of their agreement on governance lies in the institutional process (institutional process) and the rules of the game over the authority of policymaking (authoritative decisionmaking), while the difference lies in the specific terms and normativity (terms of institutional processes and outcomes), grindle, 19974 [4].

Governance is the involvement of all stakeholders in the process of determining and implementing public policies which is characterized by the interdependence of network actors, the resources they exchange, common goals, norms, and agreements negotiated between them from time to time, koliba, 2019 [5]. Various approaches to the concept of governance have emerged along with the development of studies and research conducted which include collaborative governance, policy networks and network governance as approaches in solving public problems, sorensen and trofing, 2007 [6]. The governance network perspective focuses on relations between governments and with actors such as civil society and the public sector in terms of improving coordination between organizations and the quality of policy making and service delivery klijn and koppenjan, 2016 [7].

The focus of the study of governance network as an idea in supporting public problems and needs, is used in almost all sectors of government governance, including the development of superior regional commodities that are oriented towards public goods and public interest. One of them is in terms of developing featured commodities in each region. In Indonesia itself, the problem of developing regional featured commodities still requires more attention from various groups, especially in the midst of the current covid-19 pandemic, where many parties really need an innovative and creative breakthrough related to empowering regional superior potentials to be used as a source of regional income.

And society. The enactment of the minister of home affairs regulation number 9 of 2014 [8] concerning guidelines for the development of regional superior products (pud), mandates local governments to compile and determine regional superior products (pud) every year (article 2 paragraph 1). Pud is determined based on 12 (twelve) normative criteria as a benchmark. In general, the production of several featured commodities in central mamuju regency fluctuates from year to year.

The involvement of various parties must be incorporated in a common institution regulated by regulations and joint commitments and incorporated in a network structure that is oriented as a manifestation of creating a superior commodity development model with a local-based governance network approach that focuses attention on the dimensions of the governance network, namely capital, bond models, policy tools, administrative strategies, accountability structures, and performance management systems, to optimize the process of achieving the goals of developing featured commodities in central mamuju regency. A conceptual approach based on governance network is needed by involving multi actors for sustainable development of featured commodities in central mamuju regency. 


\section{Governance network}

Departing from this explanation, rhodes, 2017 [9] describes some of the main characters of governance. First, governance has a broader meaning than government by involving nonstate actors who create interdependence between organizations. Second, the continuity of the interaction relationship between members because it is motivated by the need for exchange of resources and negotiations to share together. Third, rooted in a relationship of mutual trust and regulated by regulations resulting from negotiations and agreements between actors. Fourth, it has a significant degree of independence from the government.

This means that the relationship between these actors does not require the principle of accountability to the state. Several network approaches lead to the analysis of relationships that occur in the success or failure of implementing a model of governance networks. The success or failure of the network approach can be traced to its original design. The flow of information and resources in the network in the structure of governance networks is like a good map, where a good design will help the government achieve policy goals goldsmith and eggers, 2004 [10].

The concept of a governance network is a government model that refers to the horizontal nature and equality in the negotiation of regulations that regulate the joint relationship by more than one actor who is interdependent with each other and has the ability to self-organizing or self-governing in realizing common public goals. Structural knowledge comes from understanding situational knowledge that plays a role in improving systems thinking and strategic skills of participants/administrator networks. The need for structural knowledge was expressed by radin who stated that structural knowledge contains variables that can influence each other.

To ensure a network can run well, it is necessary to include variables that can explain the relationships that exist between participants to ensure a network runs well. Governance network has main variables in its concept, such as: (1) capital, (2) bond model, (3) policy tools, (4) administrative strategy, (5) accountability structure, and (6) performance management system, koliba, 2019 [5].

\section{Sustainable development}

Sustainable development as one of the paradigms of development has a main focus, namely realizing a balance of social and environmental development in order to support economic growth, suryono, 2010 [11]. The definition of sustainable development according to wced (world commission on environment and development) is that sustainable development is development that meets the needs of the present without compromising the ability of future generations to meet their own needs. Sustainable development is a simple but complex concept that not only pays attention to the value of intergenerational justice, but also values that cause different emphasis on what must be maintained and what must be developed, such as freedom, equality, solidarity, tolerance, respect for nature, and shared responsibility Roehl, 2013 [12].

Development objectives concern three things: (1) growth, productivity, and economic efficiency (growth), (2) social justice, equity, and (3) environmental protection. The concept of sustainable development, which consists in principle of mutually supportive relationships between economic, social and environmental development, facing conflicts of purpose, interests in development policy making seem to still be a vague concept. This concept of sustainable development is more of a normative idea than a prescriptive one. To make the concept of sustainable development a model that can be useful for planning, Campbell, 200313 formulated a triangular model of conflict development goals. The development goals are first, growth, productivity, and economic efficiency (growth), second, social justice, equity, and third environmental protection. 
The development objectives involve three things: (1) growth, productivity, and economic efficiency (growth), (2) social justice, equity and economic opportunity (equity), and (3) environmental protection. The concept of sustainable development, which principally consists of a mutually supportive relationship between economic, social and environmental development, faces conflicting objectives, interests in development policy making is still a vague concept. The concept of sustainable development is more of a normative idea than a prescriptive one. To make the concept of sustainable development into a model that can be useful for planning, Campbell, 2003[13] formulated a conflict triangle model of development goals. The development objectives are, first, growth, productivity, and economic efficiency (growth), second, social justice, equity, economic opportunity (equity), and thirdly environmental protection (environmental protection).

\section{Development of featured commudity}

The economic sector of a region can be divided into two groups, namely the basic sector where the advantages and disadvantages that occur in the process of meeting these needs lead to an inter-regional export and import mechanism. This means that this base industry will produce goods and services, both for the regional domestic market and the market outside the region/region. The non-basic sector is a sector with economic activity that only serves the market in its own area, and the export capacity of the regional economy is not yet developed. Rustiadi et al., 2011 [14]. Leading commodities are commodities demanded by the market whose products provide a high multiplier and are able to become an economic driver for the community.

Leading commodity is a mainstay commodity that has a strategic position, both based on technical considerations (soil and climate conditions) as well as socio-economic and institutional (technological mastery, human resource capabilities, infrastructure and local sociocultural conditions), to be developed in an area. The criteria for featured commodities according to daryanto 2010 [15] are: (1) must be able to become a prime mover of economic development. In other words, these featured commodities can make a significant contribution to increasing production, income and expenditure, (2) being able to compete with similar products from other regions (competitiveness) in the national and international markets, both in product prices, production costs and quality. Services, (3) its development must obtain various forms of support, such as security, social, cultural, information and market opportunities, institutions, intensive facilities and others.

\section{Research Method}

The methodological approach used in this research is qualitative with explanatory type to analyze and explain the role of governance network in sustainable development of featured commodities. The location of this research is in central mamuju regency, precisely at the department of agriculture and several groups of farmers who are in the area of central mamuju regency as the research locus. The analytical method or technique used in this research is descriptive qualitative, miles \& Huberman 1994 in Creswell 2009 [16].

The research focuses on the dimensions of the governance network concept: capital, bonding models, policy tools, administrative strategies, accountability structures. 


\section{Result and Discussion}

Strengthening the concept of a governance network in empowering local disabled workers certainly requires a combination of various elements as a form of resource sharing into one institution that becomes a unit to collaborate various interests to serve as a common goal. In line with what was stated by koliba 2019 [5] that there are several components in looking at the implementation of the governance network in a phenomenon including, capital, bond models, policy tools, administrative strategies, accountability structures, and performance management systems.

The importance of the involvement of components in the local governance network in implementing the empowerment of disabled workers, provides confirmation of the concept offered by koliba so that it becomes a benchmark for the successful implementation of the concept as a whole. Based on the results of observations related to the empowerment of disabled workers based on the governance network by koliba 2019 [5].

Based on the results of the study, it was found that efforts have been made to develop featured commodities in central mamuju regency with a focus on three main commodities, namely bananas, cocoa and corn. Commodity development is carried out through government work programs contained in regional action plans by focusing on commodities demanded by the market whose products provide a high multiplier and are able to become economic drivers for the community.

\section{a. Capital}

Each actor in the network has capital and is the basis for their ability to participate. Capital in this case is manifested as work programs, human and financial resources involved in efforts to develop featured commodities. In the concept of network organization, capital is a resource that needs to be exchanged as the main instrument to be used as a tool in achieving the goals of the activities of the actors involved. Work programs that are shared in regional superior commodity development activities still need to be enriched by programs that can be reached by all parties to be involved in them or in other words are not exclusive programs.

In terms of resources involved in implementing the development of featured commodities in central mamuju regency, quality improvement still needs to be done, especially in acting as actors who are members of network organizations so that it is easy to adapt and share activities and programs. Finance as one of the main capitals in the sustainable superior commodity development program still needs to be improved, not only in terms of quantity, namely the amount of funds involved in it, but also in terms of quality, which is really on target as financial assistance that is effective in its utilization in the network organization being developed.

\section{b. Regulatory model}

Developed as a result of intergovernmental and intragovernmental relations (a); structured through grants and contractual agreements $(b)$; structured through regulation. It is governance networks as a regulatory subsystem consisting of interorganizational networks, namely regulators and regulated entities (c); designed to influence the framework of public problems and policy solutions (d); formed when organizations from various sectors partner with each other to achieve public goals (e). Intergovernmental and intragovernmental relations in the model of ties to this activity are categorized as how many elements of government are involved.

In its implementation, the SKPDS that are actively involved are not only dominated by the agriculture service of central mamuju regency but also involve the roles of other skpds such as the regional development planning agency, the food security agency, as well as those in other productive sectors. 
The involvement of stakeholders in the development of featured commodities in the agricultural sector and food security should actually be contained in a networked institution that was formed with a specific purpose to deal with the problem of developing the network-based superior potential. The regional superior potential development unit which is allegedly a joint institution involving stakeholders who are oriented to share resources is still in the discussion stage. With the formation of the regional superior potential development unit, it is hoped that it will be able to have an optimal structure and clear regulations so that there is no overlapping of main tasks and functions by the actors involved and also has clear and directed guidelines regarding the implementation of its programs.

The absence of a regional superior potential development unit in central mamuju regency is an obstacle in terms of the regulatory model in a networked work organization. This greatly affects the ability of the actors to map the framework of the main problems and policies that need to be carried out related to the development of featured commodities in central mamuju regency. In practice, the formulation of the problem framework is still partial and is handled individually with each sectoral policy based on different understandings of the content of the problems that occur. The formation of a regional superior potential development unit as a regulatory model by actors will not only be filled by stakeholders from the government but will also involve other sectors such as NGOS and companies to be further involved as a partnership that will solve existing problems in the process of developing featured commodities. Area in central mamuju regency.

\section{c. Policy tools}

In policy tools, the dimensions that need to be considered are starting from the policy phase, function position, policy tools as input or outcome. The policy phase in the development of featured commodities in central mamuju regency follows the stages of the general policy process. In formulating policies, the assumption used is the urgency of the problem to be included in priority programs and to realize the vision and mission of regional heads who are members of integrated development in central mamuju regency. Sources in policy formulation are taken from data collected by interested SKPDS as well as input from NGOS that are active in the involvement of this issue.

The position of this policy function is more reflected in how far the superior commodity development programs in central mamuju regency are implemented. The process of implementing the program in question involves several parties who have superior commodity development programs, such as the department of agriculture identifying conditions and regional characteristics so that they are able to map out what commodities the potential have to be developed, farmer groups provide an overview or objective conditions in the field related to obstacles and challenges in increasing yields. Agricultural production, as well as the private sector as a supporting sector in helping increase business sustainability from an economic point of view. The involvement of actors in policy functions is not only limited to program implementation but also in the evaluation and monitoring process.

The policy device in this case is the subject and object of the policy. As the subject of policy, the actors identify the problem. Problems are identified and then solutions are sought and outlined through policies and programs. The object of the problem in this case is people with disabilities who are prepared and oriented as prospective workers who are then ready to be absorbed into various business worlds. In its implementation, there has been some coordination between the government, farmer groups and the private sector which, although not yet officially recognized as a joint activity in network organizations. 


\section{d. Administration strategies}

Through interdependence, the network coordinates the strategies of actors with different goals and preferences regarding certain problems or policy measures that exist in the relationships between network organizations. Coordination between actors has not been well established due to the absence of a regional superior potential development unit in central mamuju regency as a network organization in intervening in problems related to the development of regional featured commodities. However, apart from the fact that a regional superior potential development unit has not yet been formed in central mamuju regency, the pattern of coordination in handling these problems is still established through the coordination of government programs by the regional development planning agency of central mamuju regency.

The regional development planning agency of central mamuju regency as the leading sector program of each skpd, especially those related to the regional superior commodity development program, conducts uniformity and program adjustments so that there is no overlapping of programs and policies. The department of agriculture is more about providing seeds and agricultural equipment for farmers and prospective farmers, and on the other hand the skpd involved is present to meet the availability of tools and materials needed in the training stage.

\section{e. Accountability framework}

To ensure accountability remains in the configuration of governance networks, in addition to using administrative strategies, an accountability framework is needed to evaluate the actions that have been taken and include them back in the decision-making process as feedback. Koliba divides the accountability structure of the governance network into three frameworks: democratic frame, market frame, and administrative frame. The democratic frame process as part of accountability in the development of regional featured commodities in central mamuju regency is seen from the roles of the actors involved.

In this case, there are several parties involved, namely the relevant skpd, private and state companies and ngos. In addition, the level of community access related to programs run by stakeholders is also important in terms of the democratic frame. Farmer groups and business actors in the agricultural sector get enough information from the government as a program maker. In addition, the ngos involved are also active in coordinating with the government and the private sector regarding program information related to equipment and seeds assistance, which they then pass on to farmer groups in need.

The market frame can be seen in program production as well as the amount of budget spent in the implementation of this activity. Programs are not only dominated by the government but also by companies, such as companies providing agricultural equipment assistance, providing education and training in terms of increasing production, providing seeds. The amount of budget issued by various parties is also in accordance with the realization of the program in the field.

The vertical and horizontal relationships between the actors involved are a reflection of the administrative frame in terms of accountability for the implementation of this program. In reality on the ground, the relationship between actors is going well, starting from the relationship between the government SKPD and NGOS, as well as between the government SKPD and companies in central mamuju regency. The model of relationships that exist such as program coordination, delivery of information about the procurement of agricultural seeds and equipment assistance to how effective the implementation of the program they have planned so far. In addition, the relationship between organizational levels in these three sectors still needs to be improved through a serious joint forum as a network institution in empowering featured commodities in central mamuju regency. 


\section{f. Performance management systems}

Performance management systems are needed to be able to support the overall work of the network to run well and create better accountability within the organization and network. This is a monitoring of the performance of actors in the network in the whole series of programs. How a series of information can be translated into categories of information according to the interests of the network.

Components in the performance management system: a. Clarity of purpose, b. Measurable performance standards, c. Availability and accessibility of data, d. Utilization of data to guide decision making and action. Clarity of objectives must be an important point in launching each regional superior commodity development program in central mamuju regency. In reality, there are still programs in several skpds that do not have clear goals, this can be seen from the weak indicators available in measuring the achievement of goals.

In addition, work standards that need to be considered are the compatibility between the main tasks and functions of the actors involved with their competencies so that they often experience work orientation. Data availability and accessibility are also still low. In mamuju tengah regency, it is still not able to present distribution data on general agricultural conditions. For example, the unavailability of data on productive and unproductive lands, unavailability of data on the number of productive and less productive commodities, and the unavailability of superior potential data needed by the market as a whole in central mamuju regency.

Weaknesses for actors to implement a good performance management system, especially in terms of policy intervention to address the problem of developing featured commodities in an integrated manner. Stakeholders are serious about maximizing the availability of this data so that it can be used by several parties, not only by the government but all elements who are competent and pay attention to the development of featured commodities in an integrated manner in central mamuju regency.

\section{Conclusion}

The effectiveness of organizational governance, both public and non-public organizations, is strongly influenced by the network between organizations. The establishment of a network between all stakeholders shows that there is integration in the implementation of regional development. The integration between them will make it possible to overcome the limitations of funding and skills that have been experienced by local governments.

The governance network approach has not been fully effective in the effort to develop featured commodities in a sustainable manner in central mamuju regency, which is being seen from the analysis of the dimensions contained in the governance network, namely capital, bond models, policy tools, administrative strategies and accountability structures. This is due to the fact that a joint institution that is integrated has not been able to become a forum for sharing resources and coordinating for the achievement of program objectives.

\section{References}

[1] Dwiyanto, a., (2016). "ilmu administrasi di indonesia: mencari identitas". Yogyakarta: ugm press.

[2] Osborne, stephen p. (ed) (2010). The new public governance?. New york: routledge.

[3] Grindle, merilee s. (1980). Politics and policy implementation in the third world, princnton university press, new jersey. 
[4] Grindle, merilee s. (1997). Getting good government: capacity building in the public sector of developing countries. Boston: ma, harvard institute for international development.

[5] Koliba, christopher; jack w. Meek; asim zia. (2011). Governnace networks in public administration and public policy. Boca raton (usa): cre press

[6] Sørensen, e., and j. Torfing (eds) (2007) theories of democratic network governance, london: palgrave macmillan.

[7] Klijin, e.h. \& joop koppenjan. (2016). Governance networks in the public sector. Routledge. New york..

[8] Peraturan menteri dalam negeri nomor 9 tahun (2014): tentang pedoman pengembangan produk unggulan daerah (pud).

[9] Rhodes, r.a.w. (2017). Network governance and the differentiated polity. Oxford university press. United kingdom.

[10] Goldsmith, stephen and eggers, william d. (2004). Governing by network. Washington dc: brookings

[11] Institusion press.

[12] Suryono, agus. (2010) pengantar teori pembangunan. Malang, universitas negeri malang.

[13] Roehrl, richard alexander. (2013). Sustainable development scenarios for rio +20 : a component

[14] Of the sd21 project. New york, united nation of economic and social affairs, division for sustainable development.

[15] Campbell, scott. (2003). Green cities, growing cities, just cities? Urban planning and the contradiction of sustainable development, dalam fainstein, ed. Reading in planning theory. Blackwell publishers: oxford

[16] Rustiadi e, saefulhakim s dan panuju dr. (2011). Perencanaan dan pengembangan wilayah. Jakarta (id): crestpent dan yayasan pustaka obor indonesia.

[17] Daryanto a. 2005. Keunggulan daya saing dan teknik identifikasi komoditas unggulan dalam mengembangkan potensi ekonomi regional. Jurnal agrimedia 9 (2): $51-62$.

[18] Creswell, j.w., 2009. Research design: qualitative, quantitative, and mixed methods approaches 3rd ed. Sage publications. Thousand oaks, california. 